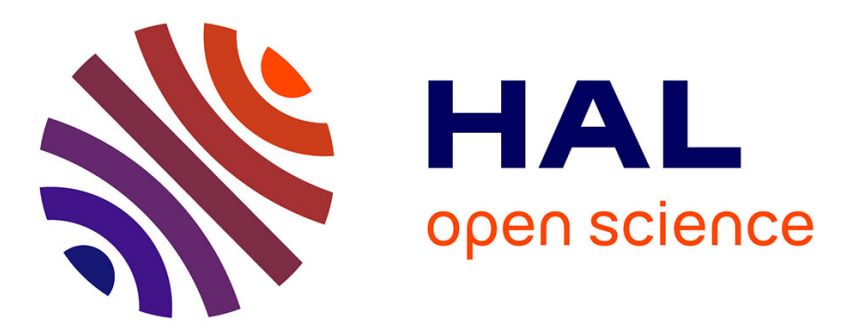

\title{
In vitro susceptibility of Varroa destructor and Apis mellifera to native strains of Bacillus thuringiensis
}

Eva Alquisira-Ramírez, José Paredes-Gonzalez, Víctor Hernández-Velázquez, José Ramírez-Trujillo, Guadalupe Peña-Chora

\section{- To cite this version:}

Eva Alquisira-Ramírez, José Paredes-Gonzalez, Víctor Hernández-Velázquez, José Ramírez-Trujillo, Guadalupe Peña-Chora. In vitro susceptibility of Varroa destructor and Apis mellifera to native strains of Bacillus thuringiensis . Apidologie, 2014, 45 (6), pp.707-718. 10.1007/s13592-014-0288-z . hal-01234771

\section{HAL Id: hal-01234771 \\ https://hal.science/hal-01234771}

Submitted on 27 Nov 2015

HAL is a multi-disciplinary open access archive for the deposit and dissemination of scientific research documents, whether they are published or not. The documents may come from teaching and research institutions in France or abroad, or from public or private research centers.
L'archive ouverte pluridisciplinaire HAL, est destinée au dépôt et à la diffusion de documents scientifiques de niveau recherche, publiés ou non, émanant des établissements d'enseignement et de recherche français ou étrangers, des laboratoires publics ou privés. 


\title{
In vitro susceptibility of Varroa destructor and Apis mellifera to native strains of Bacillus thuringiensis
}

\author{
Eva Vianey Alquisira-Ramírez ${ }^{1}$, José Roberto Paredes-GonZalez ${ }^{2}$, \\ Víctor Manuel Hernández-Velázquez ${ }^{3}$, José Augusto Ramírez-Trujillo ${ }^{3}$, \\ Guadalupe PEÑA-CHORA ${ }^{4}$
}

\footnotetext{
${ }^{1}$ Facultad de Ciencias Agropecuarias, Universidad Autónoma del Estado de Morelos, Avenida Universidad, 1001, Colonia Chamilpa, Cuernavaca, Morelos, Mexico CP 62209

${ }^{2}$ Facultad de Ciencias Biológicas, Universidad Autónoma del Estado de Morelos, Avenida Universidad, 1001, Colonia Chamilpa, Cuernavaca, Morelos, Mexico CP 62209

${ }^{3}$ Centro de Investigación en Biotecnología, Universidad Autónoma del Estado de Morelos, Avenida Universidad, 1001, Colonia Chamilpa, Cuernavaca, Morelos, Mexico CP 62209

${ }^{4}$ Centro de Investigaciones Biológicas, Universidad Autónoma del Estado de Morelos, Avenida Universidad, 1001, Colonia Chamilpa, Cuernavaca, Morelos, Mexico CP 62209
}

Received 1 May 2013 - Revised 19 March 2014 - Accepted 10 April 2014

\begin{abstract}
Fifty-four Bacillus-like strains were isolated from dead Varroa destructor collected in 24 colonies of bees from seven apiaries. The total proteins of 22 isolates were evaluated against adult female $V$. destructor $(100 \mu \mathrm{g} / \mathrm{mL})$, but only nine caused over $80 \%$ mortality. The $\mathrm{LC}_{50}$ of EA26.1, EA3 and EA11.3 isolates were calculated. The most virulent isolate was EA26.1, as $96.7 \%$ of the mites were killed $36 \mathrm{~h}$ after treatment, and the $\mathrm{LC}_{50}$ was $1.50 \mu \mathrm{g} / \mathrm{mL}$. EA3 produced $93.3 \%$ mite mortality after $48 \mathrm{~h}$ treatment, with an $\mathrm{LC}_{50}$ of $7.1 \mu \mathrm{g} /$ $\mathrm{mL}$. Finally, EA11.3 produced $93.3 \%$ mite mortality after $60 \mathrm{~h}$ treatment, with an $\mathrm{LC}_{50}$ of $22.8 \mu \mathrm{g} / \mathrm{mL}$. Additionally, the EA3 and EA26.1 isolates were used to determine mortality on adults and larvae of worker bees of $A$. mellifera. When the 16S rRNA gene was amplified and sequenced, the three strains were found to belong to the species $B$. thuringiensis. The results showed that honey bee adults and larvae are not negatively affected by identified $B$. thuringiensis isolates, indicating that they could be successfully used for the biological control of $V$. destructor without adverse effects on adults and larvae of A. mellifera, and reduce the negative impact of this mite on colonies.
\end{abstract}

Varroa destructor / Apis mellifera / Bacillus thuringiensis / pathogenicity / virulence

\section{INTRODUCTION}

Varroa destructor Anderson and Trueman (Acari: Varroidae) is an ectoparasitic mite that feeds

Electronic supplementary material The online version of this article (doi:10.1007/s13592-014-0288-z) contains supplementary material, which is available to authorized users.

Corresponding author: G. Peña-Chora, penacg@cib.uaem.mx

Manuscript editor: Peter Rosenkranz on the haemolymph of bees Apis mellifera Linnaeus (Hymenoptera: Apidae) (Anderson and Trueman 2000). This mite is recognized as the most serious pest in beekeeping worldwide because it causes open wounds on the cuticle of the bees, weakening their immune system and allowing for the entry of microorganisms such as bacteria, fungi and viruses that cause severe damage to the bee population (Brødsgaard et al. 2000; Gliński and Jarosz 1992; Nordström 2003).

To control this mite, beekeepers currently use the following miticides: acrinathrin, amitraz, 
bromopropylate, chlordimeform, cimiazol, coumaphos, fluvalinate and flumethrin (Milani 1999). However, $V$. destructor has developed resistance to amitraz, coumaphos, fluvalinate and flumethrin (Colin et al. 1997; Elzen et al. 2000; Spreafico et al. 2001Thompson et al. 2002).

Additionally, in the case of miticides, their residue in honey and other products with higher levels than those permitted by international standards cause problems and could induce side effects in bees (Desneux et al. 2007; Kochansky et al. 2001; Martel et al. 2007; Wallner 1999).

Another way to control $V$. destructor is to use organic products such as oxalic acid, formic acid and essential oils. However, their use has not been well accepted by many beekeepers because they are difficult to apply, their effectiveness depends on the ambient temperature, and the sudden release of certain products may affect the bee brood and even cause death of bees (Bogdanov et al. 2002; Gregorc et al. 2004; Milani 2001; Desneux et al. 2007).

An alternative strategy to control $V$. destructor is the use of entomopathogenic microorganisms such as bacteria and fungi (Hamiduzzaman et al. 2012; Tsagou et al. 2004). This new approach meets the growing concern for new methods of pest control that do not pollute and are more environmentally friendly (Lacey et al. 2001; Meikle et al. 2012).

Different species of entomopathogenic bacteria have been isolated and used successfully for the regulation of many arthropod pests. The most investigated species are spore-forming bacteria, particularly those found in the Bacillaceae family, such as Bacillus thuringiensis (Bt), B. sphaericus and Paenibacillus popilliae, because they can more easily infect healthy hosts (Aronson et al. 1986; de Maagd et al. 2003). Of these species, $B$. thuringiensis is the most widely used as an agent for the biological control of pests (Schnepf et al. 1998; Lacey et al. 2001).

In sporulation, $B$. thuringiensis produces parasporal crystals consisting of proteins called $\delta$ endotoxins, which are classified into two families: Cry and Cyt, which have insecticidal activity against different insect orders, such as Lepidoptera, Diptera, Coleoptera, Hymenoptera, Homoptera,
Orthoptera and Mallophaga, as well as other organisms, such as nematodes and mites (Schnepf et al. 1998). $\delta$-endotoxins are specific, with no toxicity to humans and other organisms (Bechtel and Bulla 1976; Bravo et al. 2013; de Maagd et al. 2003; Griffitts and Aroian 2005).

$B$. thuringiensis has been isolated from soil, plant leaves, the dust of stored products, and dead insects, among other habitats (Aronson 1993; Höfte and Whiteley 1989; Schnepf et al. 1998). A large number of B. thuringiensis isolates are selected and identified annually to find new strains with high levels of activity against arthropod pests.

The objective of this study was to isolate strains of $B$. thuringiensis from dead adult females of $V$. destructor, evaluate their pathogenicity and virulence against mites, and determine their pathogenicity toward adults and larvae of $A$. mellifera worker bees.

\section{MATERIALS AND METHODS}

\subsection{Isolation of bacteria from dead adult females of Varroa destructor}

Dead adult females of $V$. destructor were collected from the bottom board and some from capped brood of hives not treated with miticides; with the help of a camel hair brush they were taken and placed individually in sterile $1.5 \mathrm{~mL}$ microcentrifuge tubes (Tsagou et al. 2004). They were then disinfected with $2 \%$ sodium hypochlorite for $10 \mathrm{~s}$ and washed twice with sterile water, and placed in microcentrifuge tubes (one mite per tube). Five hundred microliters of liquid Luria-Bertani (LB) medium was added and the contents were macerated with a sterile pipette tip, and then incubated for $72 \mathrm{~h}$ at $30{ }^{\circ} \mathrm{C}$. Finally, a loop of sporulated culture was striated into Petri dishes containing solid LB to obtain single colonies.

\subsection{Selection, preservation and multiplication of bacterial isolates}

Using a compound microscope, we selected rodshaped bacteria with a spore and a parasporal crystal. These characteristics correspond to $B$. thuringiensis (Bechtel and Bulla 1976).The isolates were stored in 
liquid LB medium plus $60 \%$ glycerol at $-20{ }^{\circ} \mathrm{C}$ in the collection of the Laboratory of Plant Parasitology at the Center for Biological Research of the Autonomous University of the State of Morelos, Mexico. The bacterial isolates were grown on solid LB medium for $72 \mathrm{~h}$ at $30{ }^{\circ} \mathrm{C}$. The culture was recovered in $1 \mathrm{~mL}$ of sterile distilled water and $1 \mathrm{mM}$ PMSF (phenyl methanesulfonyl fluoride) was added; total protein was quantified by the Bradford technique (Bradford 1976).

\subsection{Pathogenicity bioassays against Varroa destructor}

$V$. destructor young adult females were collected from drone and worker capped broods of five colonies of European honey bees. The combs were taken to the laboratory, and the drone and worker brood cells were opened. Female mites were collected with a camel hair brush and placed in sterile Petri dishes with a diameter of $9 \mathrm{~cm}$. Each Petri dish contained one white-eyed pupa for holding five test mites, and these mites were used immediately for the bioassays (Tsagou et al. 2004).

Twenty-two isolates of Bacillus-like bacteria were evaluated (EA1, EA3, EA6, EA8, EA9.3, EA11.3, EA11.2.1, EA18.1.2, EA22.1, EA23, EA26.1, EA26.2, EA27.1, EA28, EA32.2.1, EA36.2, EA40.2, EA43, EA49.1, EA49.2.1, EA88.3, EA93). These isolates were selected according to their protein expression displayed on $10 \%$ polyacrylamide gels. In all evaluations, $100 \mu \mathrm{g} / \mathrm{mL}$ of total protein was used. Water and surfactant $(25 \%$ alkyl phenol polyoxyethylene ether, $15 \%$ antifoam agent, $74 \%$ diluent) were used as a control.

Groups of $30 \mathrm{~V}$. destructor individuals were immersed in the indicated concentration (100 $\mu \mathrm{g} / \mathrm{mL}$ ) for $5 \mathrm{~s}$, and then were cast with sterile plastic mesh. Excess of moisture was removed from the mites with filter paper (Whatman No. 1). Subsequently, in microcentrifuge tubes $(1.5 \mathrm{~mL})$ five mites were placed on fresh white-eyed honeybee pupae, sealed with cotton and incubated at a temperature of $34{ }^{\circ} \mathrm{C}$ (Rodriguez et al. 2009). Six replicates, each with five young adult mites, were used for isolate and mortality was monitored every day for 7 days. The mites were considered dead when they no longer showed movement when stimulated with a brush (Shaw et al. 2002). The experimental design was completely randomized.

\subsection{Species identification of EA3, EA11.3 and EA26.1 Bacillus isolates}

Total DNA was purified from each isolate using the Gentra $^{\circledR}$ Puregene ${ }^{\circledR}$ Yeast/Bact. Kit, according to the manufacturer's instructions (QIAGEN, Germany). The 16S rRNA gene fragment was amplified with the primers reported by Aguino del Muro and Priest (1993) (direct BSH1 GCG CAA GCT TAG AGT TTG ATC CTG GCT CAG GAC G and reverse BSB2 GCG GAT CCT ACC TTG TTA CGA CTT CAC CCC AG) as follows: initial denaturation at $95{ }^{\circ} \mathrm{C}$ for $5 \mathrm{~min}$, followed by 35 cycles of denaturation $\left(95^{\circ} \mathrm{C}, 35 \mathrm{~s}\right)$, annealing $\left(62{ }^{\circ} \mathrm{C}, 42 \mathrm{~s}\right)$, and extension $\left(72{ }^{\circ} \mathrm{C}, 1: 30 \mathrm{~min}\right)$ and a final extension at $72{ }^{\circ} \mathrm{C}$ for $15 \mathrm{~min}$. The PCR products were separated by electrophoresis on a $1 \%(\mathrm{w} / \mathrm{v})$ agarose gel, and bands were excised and purified using a QIAquick ${ }^{\circledR}$ Gel Extraction kit (QIAGEN, Germany). The PCR products were sequenced at the facilities of the Biotechnology Institute of the National Autonomous University of Mexico. 16S rRNA sequences were analyzed using the blastn program of the GenBank database, National Institutes of Health.

\subsection{Virulence bioassays against Varroa destructor}

The results of the pathogenicity test, showed that EA3, EA11.3 and EA26.1 strains were those that produced higher mortality on $V$. destructor. As a result, these three strains were used to calculate the Lethal Concentration $50\left(\mathrm{LC}_{50}\right)$. Based on preliminary results, the strains were evaluated at different concentrations: the EA3 strain $(0,4,8,12,16$ and $20 \mu \mathrm{g} / \mathrm{mL})$, EA11.3 $(0,10,40,70$ and $100 \mu \mathrm{g} / \mathrm{mL})$ and EA26.1 $(0,1,2,8$ and $10 \mu \mathrm{g} / \mathrm{mL}$ ). Treatments were applied as described in the pathogenicity tests (Shaw et al. 2002). For this assay, a total of 30 young adult mites for concentration were used on 15 replicates, each with two mites placed on white-eyed pupa, and mortality was monitored every $12 \mathrm{~h}$ for 7 days (Meikle et al. 2006; Tsagou et al. 2004).

\subsection{Pathogenicity by consumption bioassays against Apis mellifera adult}

The pathogenicity of two isolates of Bacillus-like strains (EA3 and EA26.1) was evaluated because their $\mathrm{LC}_{50}$ were the lowest with the following protein 
concentrations: $1,5,25,50$ and $100 \mu \mathrm{g} / \mathrm{mL}$. Three replicates of 30 bees were used for each concentration, with a total of 90 bees (a total of 450 adult bees were used for each strain) (Shaw et al. 2002).

Combs containing mature worker bee pupae were removed from two mite-free colonies and maintained at $34{ }^{\circ} \mathrm{C}$. Groups of 10 newly emerged adult bees $(>24 \mathrm{~h}$ old) were transferred to plastic containers (clear plastic tumblers of $14 \mathrm{oz}$ ); four square centimeters were removed and covered with mosquito mesh for ventilation (Evans et al. 2009). The experimental unit was three plastic containers with 10 bees each. Two hours later, the bees were fed with different concentrations of bacterial protein mixed in a solution of $50 \%$ sucrose and $0.1 \%$ surfactant. The solution was deposited into a feed device on the top of the plastic tumbler, and delivered ad libitum (Evans et al. 2009; Higes et al. 2007; Papadopoulou-Karabela et al. 1992; Ramirez-Romero et al. 2008; US EPA 1996). Two control groups were used: one containing only $50 \%$ sucrose (1) and one with $50 \%$ sucrose and $0.1 \%$ surfactant (2) (25\% alkyl phenol polyoxyethylene ether, $15 \%$ antifoam agent, $74 \%$ diluent). The bees were kept in an incubator at $34{ }^{\circ} \mathrm{C}$, mortality was measured on the seventh day by counting the number of dead bees, those that did not move when stimulated with a camel hair brush for $15 \mathrm{~s}$ (Evans et al. 2009; Higes et al. 2007; Lindberg et al. 2000; US EPA 1996).

\subsection{Pathogenicity by dip bioassays against Apis mellifera adults}

The pathogenicity of two strains of Bacillus-like strains (EA3 and EA26.1) was evaluated with $100 \mu \mathrm{g} / \mathrm{mL}$ of protein concentration plus $0.1 \%$ surfactant. Combs containing mature worker bee pupae were removed from two mite-free colonies and maintained at $34{ }^{\circ} \mathrm{C}$. Groups of 10 newly emerged adult bees ( $>24 \mathrm{~h}$ old) were transferred to plastic containers (clear plastic tumblers of $14 \mathrm{oz}$ ); four square centimeters were removed and covered with mosquito mesh for ventilation (Evans et al. 2009). The experimental unit was three plastic containers with 10 bees each. Two hours later, plastic containers with bees were stored in a refrigerator maintained at $4{ }^{\circ} \mathrm{C}$ until the bees showed the first signs of immobility (Scheiner and Arnold, 2010). Bees were immersed individually in the indicated concentration $(100 \mu \mathrm{g} / \mathrm{mL})$ for $5 \mathrm{~s}$ using dissecting forceps. A total of 90 adult bees were used; there were three replicates for each strain (the experimental unit was three plastic containers with 10 bees each) (Shaw et al. 2002). Two control groups were used: control 1, bees immersed in water; and control 2, bees immersed in water plus $0.1 \%$ surfactant $(25 \%$ alkyl phenol polyoxyethylene ether, $15 \%$ antifoam agent, $74 \%$ diluent). The bees were kept in an incubator at $34{ }^{\circ} \mathrm{C}$ for 7 days and were fed with a solution of $50 \%$ sucrose in a feed device located on the top of the plastic tumbler, and delivered ad libitum. Mortality was measured on the seventh day (Evans et al. 2009; Higes et al. 2007; Lindberg et al. 2000; US EPA 1996).

\subsection{Pathogenicity bioassays against larvae of Apis mellifera}

The larval diet was prepared according to Kaftanoglu et al. (2010) and the diet was divided into $2 \mathrm{~mL}$ centrifuge tubes and kept at $-18{ }^{\circ} \mathrm{C}$ in a freezer until they were used. The diet was thawed and brought to $34{ }^{\circ} \mathrm{C}$ in a water bath just before feeding. Five concentrations of protein $(1,5,25,50$ and $100 \mu \mathrm{g} / \mathrm{mL})$ of the EA3 and EA26.1, strain were dissolved in the larval diet. A total of 450 larvae of 2.5-3 days old were used; there were five treatment groups (90 larvae per treatment), with three replicates, and 30 larvae in each replicate. One control group free of bacterial complex was used. The exposure to the protein was in the first and second day of feeding; for this, six aliquots of $10 \mu \mathrm{L}$ of larval food with protein concentrations were placed in a polyethylene Petri dish ( $85 \mathrm{~mm}$ in diameter) and five larvae were grafted on each aliquot. After the third day, the larvae were fed as Kaftanoglu et al. (2010). The Petri dishes were transferred into a humidity chamber, and kept there at $34^{\circ} \mathrm{C}$ and $90 \% \mathrm{RH}$. On the seventh day, when the larvae stops feeding, total mortality was quantified (Aupinel et al. 2005; Kaftanoglu et al. 2010). In order to discard the production of $\beta$-exotoxins on the two Bacillus-like strains (EA3 and EA26.1) bioassays with Musca domestica larvae were performed (Mac Innes and Bouver 2009) (see supplementary material).

\subsection{Statistical analysis}

The distribution of values obtained in each pathogenicity bioassay were analyzed by ANOVA 
and Kruskal-Wallis tests, and multiple comparison of means was performed using Tukey's test, with a significance level of 0.05 . In these cases, we used the SAS statistical program version 9.0. Angular transformation of data was performed previously. To determine the virulence of each strain against $V$. destructor, the $\mathrm{LC}_{50}$ were calculated using Probit analysis via the Polo Plus 2003 statistical program (Robertson et al. 2003).

\section{RESULTS}

\subsection{Isolation of bacteria from corpses of Varroa destructor}

From a total of 250 dead adult $V$. destructor females, 54 Bacillus-like strains were isolated. In all, the isolates were assigned a consecutive number prepending the initials EA.

\subsection{Pathogenicity bioassays against Varroa destructor}

Using a dose of $100 \mu \mathrm{g} / \mathrm{mL}$, all of the Bacilluslike isolates evaluated were pathogenic to $V$. destructor. However, nine isolates were more pathogenic producing mortality rates above $80 \%$ at $48 \mathrm{~h}$ after treatment (Figure. 1). The best results were obtained with isolate EA49.1, which showed a major protein at a molecular weight of $100 \mathrm{kDa}$, and yielded $100 \%$ mite mortality. The EA11.3 isolate, with the major protein of $95 \mathrm{kDa}$, produced $93 \%$ mortality, EA26.1 showed a protein of approximately $75 \mathrm{kDa}$, with $90 \%$ mortality and EA3 revealed a major protein of approximately $95 \mathrm{kDa}$ and recorded $86.7 \%$ mortality of $\mathrm{V}$. destructor mites. The analysis of variance for the pathogenicity of the different Bacillus-like isolates on $V$. destructor demonstrated significant differences among treatments $(P<0.0001)$.

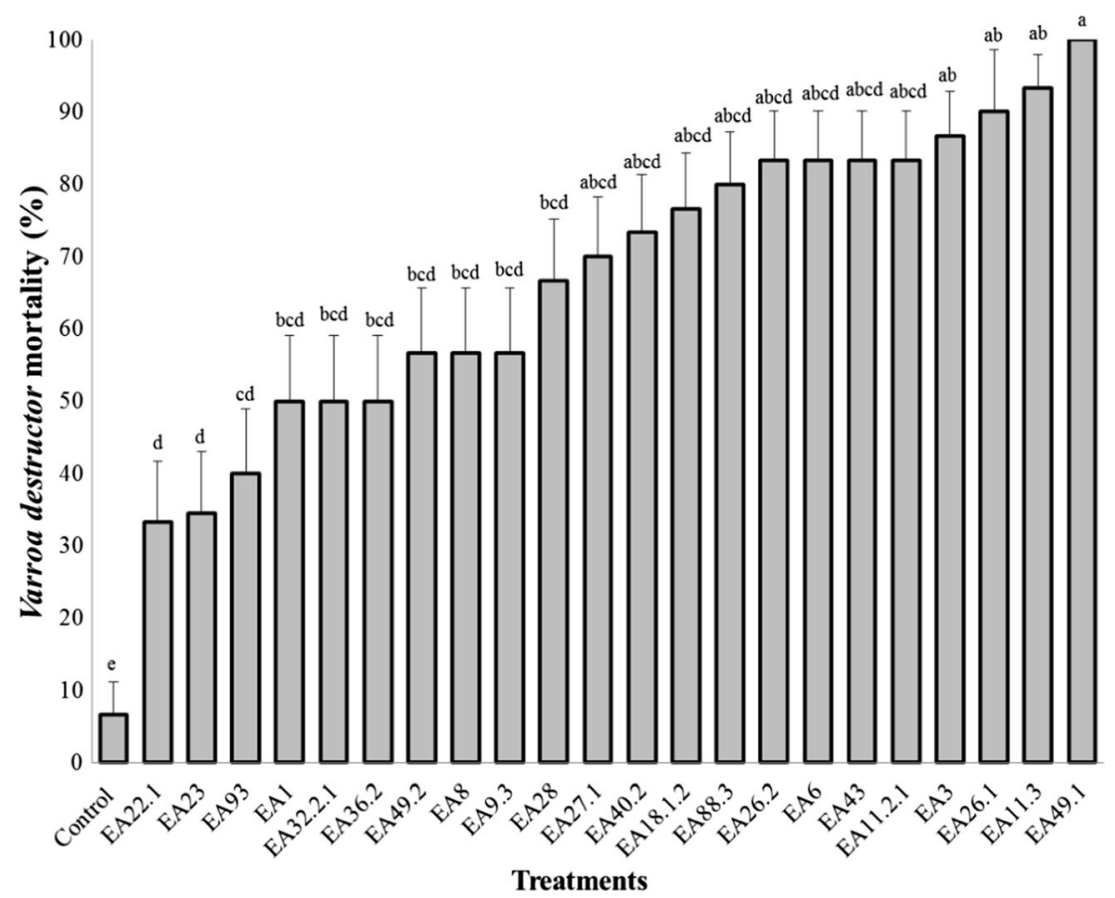

Figure 1. Mortality ( \pm SE) of Varroa destructor $48 \mathrm{~h}$ after treatment at $100 \mu \mathrm{g} / \mathrm{mL}$ by different Bacillus-like isolates. The different letters above the bars indicate differences among treatments as determined by Tukey's test $(P<0.05)$. 


\subsection{Species identification of EA3, EA11.3 and EA26.1 Bacillus-like isolates}

16S rRNA genes were sequenced and compared with the sequences available in GenBank. BLAST searching allows for rapid searching of related sequences. The isolates, EA3 and EA11.3, showed $100 \%$ identity with the $B$. thuringiensis serovar tenebrionis strain MMML-49, and EA26.1 matched $100 \%$ with the $B$. thuringiensis serovar kurstaki strain HD73. The 16S rRNA gene sequences of isolates EA3, EA11.3 and EA26.1 were deposited in GenBank with the following accession numbers: KC758845, KC758846 and $\mathrm{KC} 758847$, respectively.

\subsection{Virulence bioassays against Varroa destructor}

Three $B$. thuringiensis isolates (EA3, EA11.3 and EA26.1) that killed more than $80 \%$ of the mites at $100 \mu \mathrm{g} / \mathrm{mL}$ were selected and the $\mathrm{LC}_{50}$ (Lethal Concentration to kill $50 \%$ of the population) was determined for each (Table I). EA26.1 isolate produced $96.7 \%$ mortality at $36 \mathrm{~h}$ after treatment, and the $\mathrm{LC}_{50}$ was $1.5 \mu \mathrm{g} / \mathrm{mL}\left(\chi^{2}=\right.$ 1.28). The EA3 isolate produced $93.3 \%$ mortality at $48 \mathrm{~h}$ after treatment, and the $\mathrm{LC}_{50}$ was $7.1 \mu \mathrm{g} /$ $\mathrm{mL}\left(\chi^{2}=1.84\right)$. The EA11.3 isolate produced $93.3 \%$ mortality $60 \mathrm{~h}$ after treatment, and the $\mathrm{LC}_{50}$ was $22.8 \mu \mathrm{g} / \mathrm{mL}\left(\chi^{2}=1.47\right)$. The results of this study indicate that the EA26.1 isolate was more effective because it killed more mites in relation to the EA11.3 and EA3 isolates at lower protein concentrations.

\subsection{Pathogenicity bioassays against adult and larvae of Apis mellifera}

After $A$. mellifera adults had been ingesting the protein concentrations for 7 days, the mortality rates recorded with the EA3 isolate were considerably lower (between 2.2 and $5.6 \%$ ), but higher mortality was observed in the second control (6.7 \%) (Figure. 2). When the mortality among treatments was compared, we observed significant differences between the bees of the control group 


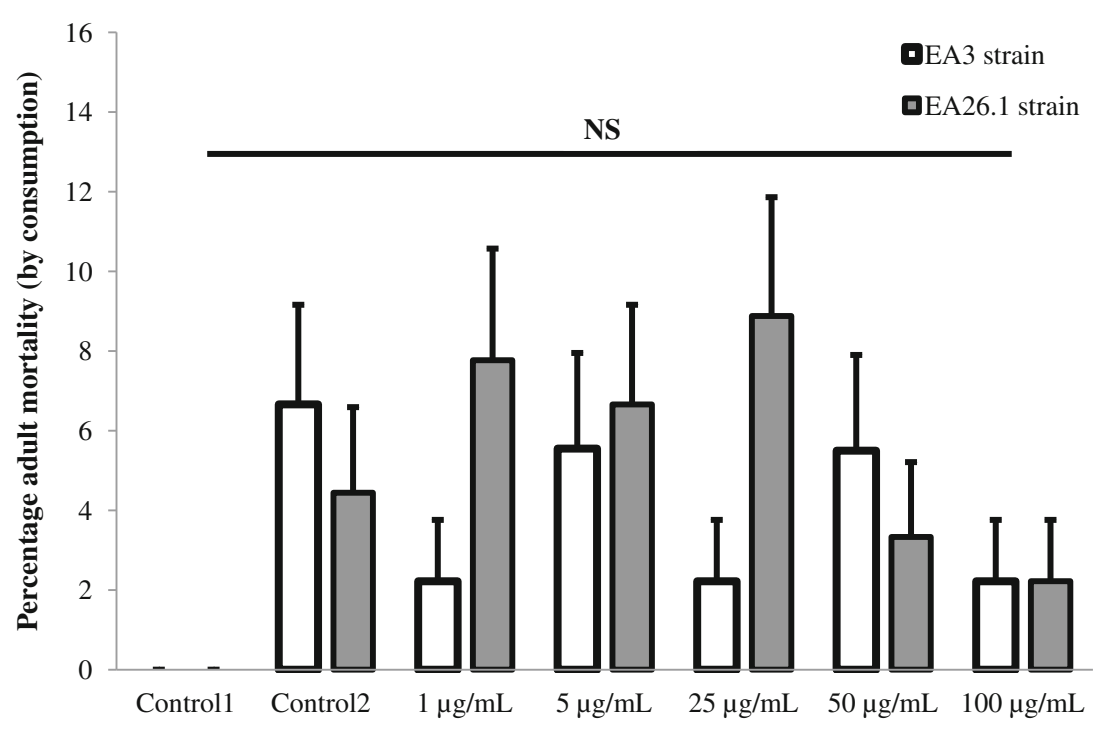

Concentrations

Figure 2. Percentage mortality ( \pm SE) of adult bees 7 days after being fed different protein concentrations of the EA3 (white bars) and EA26.1 (grey bars) strains. Control 1, bees fed with $50 \%$ sucrose, and control 2, bees fed with $50 \%$ sucrose plus $0.1 \%$ surfactant.

that did not receive surfactant and the control group that did receive surfactant (second control), but there were no significant differences among five treatments and controls $\left(\chi^{2}=13.24 ; 6 \mathrm{df} ; P=\right.$ 0.039). The EA26.1 isolate caused mortality between 2.2 and $8.9 \%$ (Figure. 2), but there were no significant differences among five treatments and controls $\left(\chi^{2}=11.05 ; 6 \mathrm{df} ; P=0.088\right)$.

Also, the mortality of adult bees treated by dip was recorded. The results with both strains (EA3 and EA26.1) showed less than $15 \%$ mortality, and no significant difference was found compared with the two control groups $\left(\chi^{2}=6.71 ; 3 \mathrm{df} ; P=0.08\right)$ (Figure 3$)$.

The larvae that were fed different concentrations of total protein of the EA3 strain, showed a percentage of mortality between 18 and $32 \%$. These are high mortalities, but the control larvae group also showed a mortality of $17 \%$ (Figure. 4). No significant difference was found among the treatments and the control group $\left(\chi^{2}=2.29 ; 5 \mathrm{df}\right.$; $P=0.80$ ). The larvae that were fed with different concentrations of total protein of the EA26.1 strain, showed a percentage of mortality between 19 and $28 \%$ (Figure. 4). In this case, the control group showed a mortality of $18 \%$. No significant difference was found among the treatments and the control group $\left(\chi^{2}=1.59 ; 5 \mathrm{df} ; P=0.90\right)$.

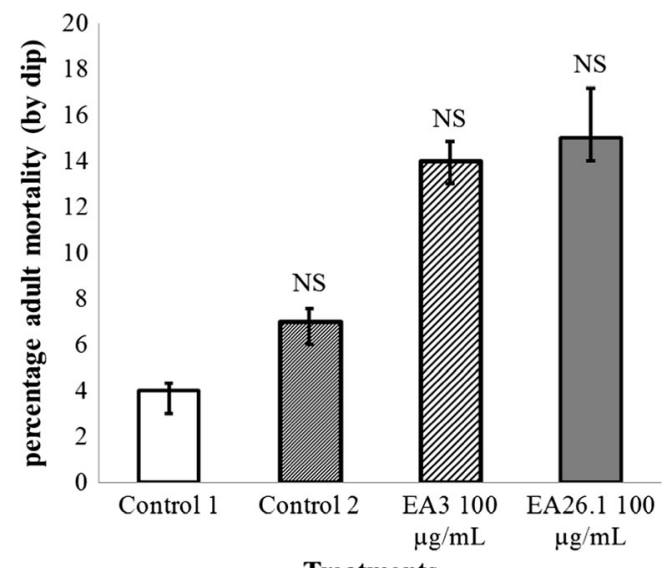

Treatments

Figure 3. Percentage mortality ( \pm SE) of adult bees 7 after dip at $100 \mu \mathrm{g} / \mathrm{mL}$ of the EA3 and EA26.1 strains. Control 1, bees immersed in water, and control 2, bees immersed in water plus $0.1 \%$ surfactant. NS: not significant from the control group (Tukey's test; $P<0.05$ ). 


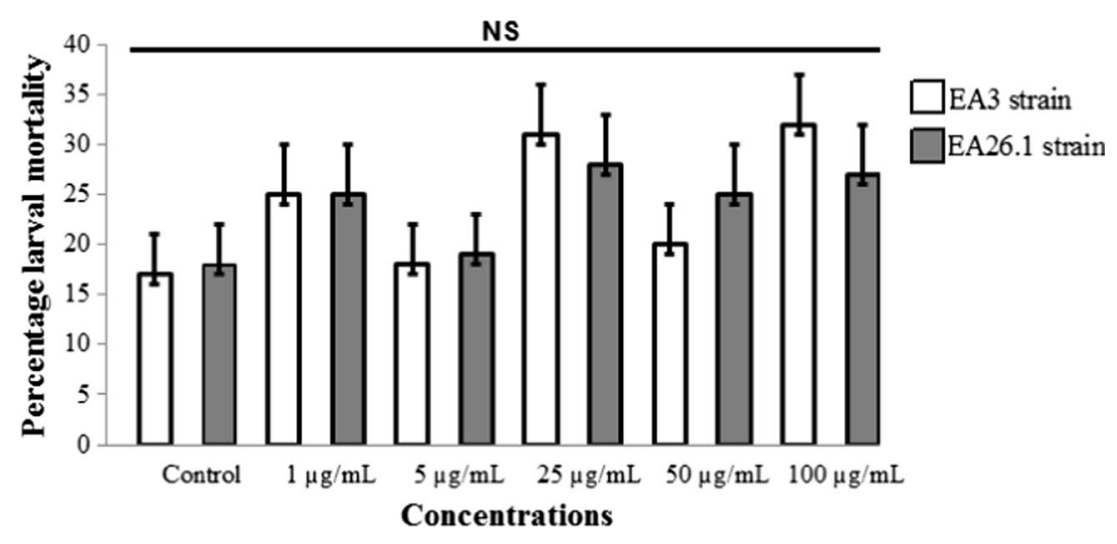

Figure 4. Percentage larval mortality $( \pm \mathrm{SE}) 7$ days after being fed with larval diet plus different protein concentrations of the EA3 (white bars) and EA26.1 (grey bars) strains. NS: not significant from the control group (Tukey's test; $P<0.05$ ).

\section{DISCUSSION}

V. destructor is the most serious pest for $A$. mellifera, and some researchers have noted that it plays an important role in the phenomenon called Colony Collapse Disorder (De Rycke et al. 2002; Martin 2001; Topolska et al. 2008). Unfortunately, $V$. destructor has developed resistance to miticides, so there is a desperate need to develop new ways to control this parasitic mite.

The results of this study show that nine Bacilluslike isolates tested for pathogenicity and three tested for virulence have a lethal effect against $V$. destructor in short time periods (36, 48 and $60 \mathrm{~h}$ ). Tsagou et al. (2004) isolated one Bacillus sp. strain from $V$. destructor which was evaluated against the same mite using $0.5 \mathrm{~mL}$ of extracellular broth and cellular extract, without quantifying protein. They report virulence with an $\mathrm{LT}_{50}$ (Lethal Time to kill $50 \%$ of the population) $4 \mathrm{~h}$ for both and an $\mathrm{LT}_{90}$ of 21 and $43 \mathrm{~h}$, respectively. Although, we did not calculate LT, more than $90 \%$ of the mites were killed at $36 \mathrm{~h}$ (EA26.1) and $48 \mathrm{~h}$ (EA3), so these isolates also kill the mites quickly.

Like Tsagou et al. (2004) we did not know which factors were involved in toxicity against $V$. destructor. Peña et al. (2006) reported a protein of a molecular weight of $100 \mathrm{kDa}$ toxic to Epilachna varivestis (Coleoptera), produced by a strain of $B$. thuringiensis which is an S-layer type. EA49.1 produces one of a similar weight. Ruiz-de Escudero et al. (2006) reported a protein Crylla7 with a molecular weight of $\sim 75 \mathrm{kDa}$, like the EA26.1 isolate, and it was toxic to Letipnotarsa decemlineata. However, it is possible that $\delta$ endotoxins (Cry and Cyt) may have played a role since they are known to be responsible for the insecticidal activity of $B$. thuringiensis on a large number of different insect species (Bravo et al. 2007). After $24 \mathrm{~h}$ of treatment, some mites were trembling; also, regurgitation and dysentery were observed, this suggest that the activity of the proteins of these B. thuringiensis, could be similar to the reported for Cryl toxins by Bravo et al. (2004).

Several reports have shown that when a $B$. thuringiensis strain is isolated from corpses, it is pathogenic to the same insect species. Angus and Norris (1968) isolated three strains of $B$. thuringiensis from corpses of Bombyx mori L., and all were toxic to this insect species; the strain HD1 of $B$. thuringiensis was isolated from a corpse of Pectinophora gossypiella (Saunders) by Dulmage (1970); it is the active ingredient of all commercial bioinsecticides, and is toxic to more than 100 species of Lepidoptera. Krieg et al. (1983) isolated from Tenebrio molitor L. dead larvae a $B$. thuringiensis isolate that is toxic to several species of Coleoptera.

On the other hand, biosafety tests on beneficial insects are very important and are required 
before the introduction of an entomopathogenic into the field to control a pest.

The results of our studies show that the strains used in this study are not pathogenic in vitro to adults and larvae of $A$. mellifera; bees were subjected to high concentration of total protein of $B$. thuringiensis. In the case of the tests made with the EA3 strain, bees were treated with a concentration 14 times the $\mathrm{LC}_{50}$ found for $V$. destructor. In the case of the tests made with the EA26.1 strain, bees were treated with a concentration 67 times the $\mathrm{LC}_{50}$ found for $V$. destructor. In all cases, the mortality of bees was not significant compared to the control groups. Bacillus thuringiensis produces Cry1 proteins that are pore-forming toxins; upon ingestion, the crystals are solubilized and activate by midgut proteases, monomers bind cadherina-like receptors, the $\alpha-1$ is cleaved and oligomeric pre-pore structure is formed, then the oligomers bind to APN (aminopeptidase N) and move to the DMR (detergent-resistant membrane microdomains) it inserts into the membrane and forms the pore that kills the cells (Bravo et al. 2004). However, not all insect species have the same receptors or midgut proteases; these could make them susceptible or resistant to $B$. thuringiensis toxins (Gomez et al. 2014). Honey bees are fed mainly carbohydrates and proteins, and also lipids, vitamins and minerals (Brodschneider and Crailsheim 2010), so they could have different midgut proteases which inactivate the $B$. thuringiensis proteins that are toxic to the adults of $V$. destructor.

Something that is important to note in this study is that, in all tests on adults and larvae, the mortality period of observation was 7 days, which is longer than that specified by the Office of Prevention Pesticides and Toxic Substances (OPPTS) and the United States Environmental Protection Agency (EPA), which indicates that the test duration is $48 \mathrm{~h}$ (US EPA 1996). This suggests that bees (including larvae) are tolerant to high concentrations of EA3 and EA26.1 strains of $B$. thuringiensis.

The EA3 and EA26.1 isolates produced less than $15 \%$ mortality in adult bees, but when we compare the mortality from the control groups, we see that the surfactant-free controls (control 1) showed mortalities of $0 \%$ in the diet treatments and $4 \%$ the dip treatments. Contrary to this, the control groups containing surfactant (control 2) showed $7 \%$ mortality in both tests (diet and dip treatments). This suggests that some components of the surfactant could be toxic to bees (Timothy et al. 2012). Therefore, special testing is needed to see if the surfactants used in this study produced adverse effects on honey bees.

There is concern about using $B$. thuringiensis strains producing $\beta$-exotoxins as a bioinsecticide, because it is known that these toxins are highly toxic to insects, and in some cases to mammals, and also are mutagenic because of its structural analogy to ATP (Šebesta et al. 1981). The mortality caused to adult $V$. destructor by EA3 and EA26.1 B. thuringiensis strains are not due to $\beta$-exotoxins which are thermostable, because no mortality or pupae malformation was observed on the larvae of $M$. domestica treated with the autoclaved supernatants (see supplementary material). So these strains could be used to control $V$. destructor without any adverse effects on bees.

To date, research regarding the effect of $B$. thuringiensis in bees has focused on toxins that are expressed in genetically engineered plants. These studies indicate that the CrylAb, Cry1Ac, CrylAh and Cry1Ba toxins of B. thuringiensis are not lethal toward adult bees. Despite several days of feeding a diet contaminated with toxins, the survival rates are upwards of $80 \%$ (Babendreier et al. 2005; Malone et al. 1999; Han et al. 2010; Ping-Li et al. 2012; Ramirez-Romero et al. 2008). So far, there are no reports indicating that the Cry proteins of $B$. thuringiensis are directly toxic to $A$. mellifera (Chilcutt and Tabashnik 1999; Duan et al. 2008; Walker et al. 2007).

Additionally, bees maintain a wide range of bacterial taxa in their digestive system, which are capable of inhibiting the growth of pathogens such as Paenibacillus larvae (Evans and Tamieka-Nicole 2006). The majority of bacteria in the digestive tract belong to the genus Bacillus, suggesting a stable symbiosis between bees and this bacterial taxon. This could explain why bees are more tolerant to $B$. thuringiensis than other insects (Evans and Tamieka-Nicole 2006; Gilliam 1997, 1978). 
Despite the huge problem that $V$. destructor represents in beekeeping, research studies on its biological control are very limited. Therefore, it is necessary to continue these investigations not only in laboratory conditions, but also in field conditions.

\section{ACKNOWLEDGEMENTS}

We thank Marisa Mendoza Flores for providing the hives infested with $V$. destructor. E. V.A.R. acknowledges the Consejo Nacional de Ciencia y Tecnología for the $\mathrm{PhD}$ fellowship, and the four anonymous reviewers for the improvement of the manuscript.

Susceptibilité in vitro de Varroa destructor et d'Apis mellifera à des souches naturelles de Bacillus thuringiensis

Apidae / pathogénicité / virulence / Acari / ectoparasite

In vitro-Empfindlichkeit von Varroa destructor und Apis mellifera gegenüber einheimischen Stämmen von Bacillus thuringiensis

Varroa destructor / Apis mellifera / Bacillus thuringiensis / Pathogenität / Virulenz

\section{REFERENCES}

Aguino del Muro, M., Priest, F.G. (1993) Phylogenetic analysis of Bacillus sphaericus and development of an oligonucleotide probe specific for mosquitopathogenic strains. FEMS Microbiol. Lett. 112 (2), 205-210

Anderson, D.L., Trueman, J.W.H. (2000) Varroa jacobsoni (Acari: Varroidae) is more than one species. Exp. Appl. Acarol. 24 (3), 165-189

Angus, T.A., Norris, J.A. (1968) A comparison of the toxicity of some varieties of Bacillus thuringiensis Berliner for silkworm larvae. J. Invertebr. Pathol. 11, 289-295

Aronson, A.I. (1993) The two faces of Bacillus thuringiensis: insecticidal proteins and postexponential survival. Mol. Microbiol. 7(4), 489-496

Aronson, A.I., Beckman, W., Dunn, P. (1986) Bacillus thuringiensis and related insect pathogens. Microbiol. Rev. 50, 1-24

Aupinel, P., Fortini, D., Dufour, H., Tasei, J.-N., Michaud, B., Odoux, J.-F., Pham-Delègue, M.-H.
(2005) Improvement of an artificial feeding in a standard in vitro method for rearing Apis mellifera larvae. B. Insectol. 58 (2), 107-111

Babendreier, D., Kalberer, N.M., Romeis, J., Fluri, P., Mulligan, E., Bigler, F. (2005) Influence of Bttransgenic pollen, Bt-toxin and protease inhibitor (SBTI) ingestion on development of the hypopharyngeal glands in honeybees. Apidologie 36 (4), 585-594

Bechtel, D.B., Bulla, L.A. (1976) Electron microscope study of sporulation and parasporal crystal formation in Bacillus thuringiensis. J. Bacteriol. 127 (3), 1472-1481

Bogdanov, S.J., Charrière, D., Imdorf, A., Kilchenmann, V., Fluir, P. (2002) Determination of residues in honey after treatments with formic and oxalic under field conditions. Apidologie 33 (4), 399-409

Bradford, M.M. (1976) A rapid and sensitive method for the quantitation of microgram quantities of protein utilizing the principle of protein-dye binding. Anal. Biochem. 72 (1-2), 248-254

Bravo, A., Gomez, I., Conde, J., Muñoz-Garay, C., Sánchez, J., Miranda, R., Zhuang, M., Gill, S.S., Soberon, M. (2004) Oligomerization triggers binding of a Bacillus thuringiensis Cry1 Ab pore-forming toxin to aminopeptidase $\mathrm{N}$ receptor leading to insertion into membrane microdomains. Biochim. Biophys. Acta. 1667 (1), 38-46

Bravo, A., Gill, S.S. Soberon, M. (2007) Mode of action of Bacillus thuringiensis Cry and Cyt toxins and their potential for insect control. Toxicon 49 (4), 423-435

Bravo, A., Gomez, I., Porta, H., Garcia-Gomez, B.I., Rodriguez-Almazan, C., Pardo, L., Soberon, M. (2013) Evolution of Bacillus thuringiensis Cry toxins insecticidal activity. Microb. Biotechnol. 6 (1), 17-26

Brodschneider, R., Crailsheim, K. (2010) Nutrition and health in honey bees. Apidologie 41 (3), 278-294.

Brødsgaard, C.J., Ritter, W., Hansen, H., Brødsgaard, H.F. (2000) Interactions among Varroa jacobsoni mites, acute paralysis virus, Paenibacillus larvae larvae and their influence on mortality of larval honeybees in vitro. Apidologie 31 (4), 543-554

Chilcutt, C.F., Tabashnik, B.E. (1999) Effects of Bacillus thuringiensis on adults of Cotesia plutellae (Hymenoptera: Braconidae), a parasitoid of the diamondback moth, Plutella xylostella (Lepidoptera: Plutellidae). Biocontrol Sci. Technol. 9 (3), 435-440

Colin, M.E., Vandame, R., Jourdan, P., Di Pasquele, S. (1997) Fluvalinate resistance of Varroa destructor Oudemans (Acari: Varroidae) in mediterranean apiares of France. Apidologie 28 (6), 375-384

de Maagd, R.A., Bravo, A., Berry, C., Crickmore, N., Schnepf, H.E. (2003) Structure, diversity, and evolution of protein toxins from spore-forming entomopathogenic bacteria. Annu. Rev. Gen. 37, 409-433

De Rycke, P.H., Joubert, J.J., Hosseinian, S.H., Jacobs, F.J. (2002) The possible role of Varroa destructor in the spreading of American foulbrood among apiares. Exp. Appl. Acarol. 27(4), 313-318 
Desneux, N., Decourtye, A., Delpuech, J.M. (2007) The sublethal effects of pesticides on beneficial arthropods. Annu. Rev. Entomol. 52: 81-106

Duan, J.J., Marvier, M., Huesing, J., Dively, G., Huang, Z.Y. (2008) A meta-analysis of effects of Bt crops on honey bees (Hymenoptera: Apidae). PLoS ONE 3 (1), e1415. doi:10.1371/journal.pone.0001415

Dulmage, H.T. (1970) Insecticidal activity of HD1, a new isolate of Bacillus thuringiensis var. alesti. J. Invertebr. Pathol. 15, 232-239

Elzen, P.J., Baxter, J.R., Spivac, M., Wilson, W.T. (2000) Control of Varroa jacobsoni Oud. resistant to fluvalinate and amitraz using coumaphos. Apidologie 31 (3), 437-441

Evans, J.D., Tamieka-Nicole, A. (2006) Antagonistic interactions between honey bee bacterial symbionts and implications for disease. BMC Ecol. 6, 4

Evans, J.D., Chen, Y.P., Prisco, G., Pettis, J., Williams, V. (2009) Bee cups: single-use cages for honey bee experiments. J. Apic. Res. 48 (4), 300-302

Gilliam, M. (1978) Bacteria belonging to the genus Bacillus isolated from honey bees, Apis mellifera, fed 2, 4-d and antibiotics. Apidologie 9 (3), 213-222

Gilliam, M. (1997) Identification and roles of nonpathogenic microflora associated with honey bees. FEMS Microbiol. Lett. 155 (1), 1-10

Gliński, Z., Jarosz, J. (1992) Varroa jacobsoni is a carrier of bacterial infections to a recipient bee host. Apidologie 23 (1), 25-31

Gomez, I., Sanchez, J., Muñoz_Garay, C., Matus, V., Gill, S.S., Soberon, M., Bravo, A. (2014) Bacillus thuringiensis toxins are versatile-proteins with multiple modes of action: two distinct pre-pores are involved in toxicity. Biochem. J. doi:10:1042/BJ20131408

Gregorc, A., Pogačnik, A., Bowen, I.D. (2004) Cell death in honeybee (Apis mellifera) larvae treated with oxalic or formic acid. Apidologie 35 (5), 453-460

Griffitts, S., Aroian, R.V. (2005) Many roads to resistance: how invertebrates adapt to $B t$ toxins. Bioessays 27 (6), 614-624

Hamiduzzaman, M.M., Sinia, A., Guzman-Navoa, H., Goodwin, P.H. (2012) Entomopathogenic fungi as potential biocontrol agents of the ecto-parasitic mite, Varroa destructor and their effect on the immune response of honey bees (Apis mellifera L.). J. Invertbr. Pathol. 111 (3), 237-243

Han, P., Chang-Ying, N., Chao-Liang, L., Jin-Jie, C., Desneux, N. (2010) Quantification of toxins in a Cry1Ac + CpTI cotton cultivar and its potential effects on the honey bee Apis mellifera L. Ecotoxicology 19 (8), 1452-1459

Higes, M., García-Palencia, P., Martín-Hernández, R., Aránzazu, M. (2007) Experimental infection of Apis mellifera honeybees with Nosema ceranae (Microsporidia). J. Invertebr. Pathol. 94 (3), 211-217

Höfte, H., Whiteley, H.R. (1989) Insecticidal crystal proteins of Bacilllus thuringiensis. Microbiol. Rev. 53, 242-255
Kaftanoglu, O., Linksvayer, T.A., Page, R.E. (2010) Rearing honey bees, Apis mellifera, in vitro I. Effects of sugar concentrations on survival and development. J. Insect Sci. 11:96 available on line: inscetscience.org/11.96

Kochansky, J., Wilzer, K., Feldlaufler, M. (2001) Comparison of the transfer of coumaphos from beewax into syrup and honey. Apidologie 32 (2), 119-125

Krieg, V.A., Huger, A.M., Langenbruch, G.A., Schnetter, W. (1983) Bacillus thuringiensis var. tenebrionis, a new pathotype effective against larvae of Coleoptera. Z. Angew. Entomol. 96, 500-508

Lacey, L.A., Frutos R., Kaya, H.K., Vail, P. (2001) Insect pathogens as biological control agents: do they have a future? Biol. Control 21 (3), 230-248

Lindberg, C.M., Melathopoulos, A.P., Winston, M.L. (2000) Laboratory evaluation of miticides to control Varroa jacobsoni (Acari: Varroidae), a honey bee (Hymenoptera: Apidae) parasite. J. Econ. Entomol. 93 (2), 189-198

Mac Innes, T.C., Bouver, G. (2009) An improved bioassay for the detection of Bacillus thuringiensis $\beta$-exotoxin. J. Invertebr. Pathol. 101, 137-139

Malone, L.A., Burgess, E.P., Stefanovic, D. (1999) Effects of a Bacillus thuringiensis toxin, two Bacillus thuringiensis biopesticide formulations, and a soybean trypsin inhibitor on honey bee (Apis mellifera L.) survival and food consumption. Apidologie 30 (6), 465-473

Martel, A.C., Zeggane, S., Aurières, C., Drajnudel, P., Faucon, J.P., Aubert, M. (2007) Acaricide residues of honey and wax after treatment of honey bee colonies with Apivar ${ }^{\circledR}$ and Asuntol ${ }^{\circledR} 50$. Apidologie 38 (6), 534-544

Martin, S.J. (2001) The role of Varroa and viral pathogens in the collapse of honeybee colonies: a modelling approach. J. Appl. Ecol. 38 (5), 1082-1093

Meikle, W.G., Mercadier, G., Girod, V., Derouané, F., Jones, W.A. (2006) Evaluation of Beauveria bassiana (Balsamo) Vuillemin (Deuteromycota: Hyphomycetes) strains isolated from varroa mites in southern France. J. Apic. Res. 45 (4), 219-220

Meikle, W.G., Sammataro, D., Neumann, P., Pflugfelder, J. (2012) Challenges for developing pathogen-based biopesticides against Varroa destructor (Mesostigmata: Varroidae). Apidologie 43 (5), 501-514

Milani, N. (1999) The resistance of Varroa jacobsoni Oud. to acaricides. Apidologie 30 (2-3), 229-234

Milani, N. (2001) Activity of oxalic and citric acids on the mite Varroa destructor in laboratory assays. Apidologie 32 (2), 127-138

Nordstrőm, S. (2003) Distribution of deformed wing virus within honey bee (Apis mellifera) brood cells infested with ectoparasitic mite Varroa destructor. Exp. Appl. Acarol. 29 (3-4), 293-302

Papadopoulou-Karabela, K., Iliadis, N., Liakos, V., Bourdzy-Hatzopoulou, E., (1992) Experimental infection of honeybees by Pseudomonas aeruginosa. Apidologie 23 (5), 393-397 
Peña, G., Miranda-Rios, J., de la Riva, G., Pardo-López, L., Soberón, M., Bravo, A. (2006) A Bacillus thuringiensis s-layer protein involved in toxicity against Epilachna varivestis (Coleoptera: Coccinellidae). Appl. Environ. Microbiol. 72 (1), 353-360

Ping-Li, D., Zhou, W., Zhang, J., Hong-Juan, C., Wang, Q., Wei-Yu, J., Ji-Hu, S., Yan-Yan W., Zhou, T. (2012) Field assessment of Bt Cry1Ah corn pollen on the survival, development and behavior of Apis mellifera ligustica. Ecotox. Environ. Safe. (79), 232-237

Ramirez-Romero, R., Desneux, N., Decourtye, A., Chaffiol, A., Pham-Delégue, M.H. (2008) Does Cryl $\mathrm{Ab}$ protein affect learning performances of the honey bee Apis mellifera L. (Hymenoptera, Apidae)? Ecotox. Environ. Safe. 70 (2), 327-333

Ruiz-de Escudero, I., Estela, A., Porcar, M., Martinez, C., Oguiza, J.A., Escriche, B., Ferre, J., Caballero, P. 2006. Molecular and insecticidal characterization of a Cry1I protein toxic to insects of the families Noctuidae, Tortricidae, Plutellidae and Chrysomelidae. Appl. Environ. Microbiol. 72 (7), 4796-4804

Robertson, J.L., Preisler, H.K., Russell, R.M. (2003) PoloPlus. Probit and logit analysis. LeOra software 2002-2003

Rodriguez, M., Gerding, M., France, A. (2009) Selection of entomopathogenic fungi to control Varroa destructor (Acari: Varroidae). Chilean J. Agric. Res. 69 (4), 534-540

Scheiner, R., Arnold, G. 2010. Effects of patriline on gustatory responsiveness and olfactory learning in honey bees. Apidologie 41 29-37

Schnepf, E., Crickmore, N., van Rie, J., Lereclus, D., Baum, J., Feitelson, J., Zeigler, D.R., Dean, D.H. (1998) Bacillus thuringiensis and its pesticidal crystal proteins. Microbiol. Mol. Biol. Rev. 62, 775-806

Šebesta, K., FarkaŠ, J., Horska, K. (1981) Thuringiensin, the Beta-exotoxin of Bacillus thuringiensis, in: Burges, H.D (Ed), Microbial control of pests and plant diseases 19701980. Academic Press, pp. 249-281
Shaw, K.E., Davison, G., Clark, S.J., Ball, B.V., Pell, J.K., Chandler, D., Sunderland, K.D. (2002) Laboratory bioassays to assess the pathogenicity of mitosporic fungi to Varroa destructor (Acari: Mesostigmata), an ectoparasitic mite of honeybee, Apis mellifera. Biol. Control 24 (3), 266-276

Spreafico, M., Eördegh, F.S., Bernardinelli, I., Colombo, M. (2001) First detection of strains of Varroa destructor resistant of coumaphos. Results of laboratory tests and field trials. Apidologie 32 (1), 49-55

Thompson, H.M., Brown, M.A., Ball, R.F., Bew, M.H. (2002) First report of Varroa destructor resistance to pyrethroids in the UK. Apidologie 33 (4), 57-366

Timothy, J.C., Mullin, C.A., Frazier, J.L., Schmehl, D.R. (2012) Learning impairment in honey bees caused by agricultural spray adjuvants. PLoS ONE 7 (7), e40848. doi:10.1371/journal.pone.0040848

Topolska, G., Gajda, A., Hartwig, A. (2008) Polish honey bee colony-loss during the winter of 2007/ 2008. J. Apic. Sci. 52 (2), 95-104

Tsagou, V., Lianou, A., Lazarakis, D., Emmanouel, N., Aggelis, G. (2004) Newly isolated bacterial strains belonging to Bacillaceae (Bacillus sp.) and Micrococcaceae accelerate death of the honey bee mite, Varroa destructor ( $V$. jacobsoni), in laboratory assays. Biotechnol. Lett. 26 (6), 529-532

US EPA (1996) Honey bee acute contact toxicity test (OPPTS 850.3020). Ecological effects test guidelines, EPA 712-C-96-147, Washington, DC.

Walker, G.P., Cameron, P.J., MacDonald, F.M., Madhusudhan, V.V., Wallace A.R. (2007) Impacts of Bacillus thuringiensis toxins on parasitoids (Hymenoptera: Braconidae) of Spodoptera litura and Helicoverpa armigera (Lepidoptera: Noctuidae). Biol. Control 40 (1), 142-151

Wallner, K. (1999) Varroacides and their residues in bee products. Apidologie 30 (2-3), 235-248 